\title{
Nanowires' display of potential
}

\section{ナハワイヤーを利用したデイスプレイの可能性}

Hagen Klauk

ビデオディスプレイの未来は、柔軟かつ透明である。小型で、屈曲性があり、透明な付随的電子 機器を製作するための材料を見つけることはむずかしい。けれども、有望な候補が現れ始めている。

Nature Vol.451 (533-534) / 31 January 2008

半導体ナノワイヤーは非常に小さな半導体結晶であ り、一般的な長さは数 $\mu \mathrm{m}$ 、直径はわずか 20 80nm しかない。これが、極小のマイクロプロセッサ やテラビット級のメモリチップなど、次世代の集積回 路の基礎となる可能性がある。専門家らは、ナノワイ ヤーの小ささを利用してシリコン基板上に $1 \mathrm{~cm}^{2}$ あた り 2000 億個ものナノワイヤー・トランジス夕を詰め 込むことで、こうした素子をそこそこのコストで製造 できるようになることを期待している。そのためには、 トランジスタが従来の平面的なレイアウトから脱却す ることも必要となるだろう1。

ゴールはまだまだ先であるが、ナノワイヤー・トラ ンジスタはすでに、集積密度やスイッチング速度の 要求水準がもつと低い分野への応用において、独自 のニッチを切り開きつつある。その一例として Ju ら ${ }^{2}$ は、ナノワイヤー・トランジスタの特殊な性質が、ア クティブマトリックス式有機発光ダイオード（OLED） ディスプレイでの使用に適していることをNano Letters 誌にて示している。

こうしたディスプレイの個々の画素には、OLEDの ほかに、いくつかのトランジス夕を入れなければなら ない。トランジスタを入れるのは、フルモーションで のビデオ再生の際に画像が高速で変化しているとき にも、すべての画素が必要な色を必要な明るさで発 せられるようにするためである。ディスプレイの単位 面積当たりのトランジスタの個数は比較的少ないため $\left(1 \mathrm{~cm}^{2}\right.$ あたり 1 万個前後)、個々のトランジスタが 占める面積は、メモリチップやマイクロプロセッサチッ プの場合ほど重要ではない。

実用面では、OLED ディスプレイ中のトランジスタ に、アモルファスシリコン ${ }^{3,4}$ や共役オリゴマー ${ }^{2}$ のよ
うな電荷担体の移動度が比較的低い半導体を使用 できるという意味がある。移動度が小さいということ は、十分な電荷担体を輸送し、必要な電流 (1 画 素につき約 $10^{-5}$ アンペア）を駆動できるだけの大き さ(つまり幅の広さ) がトランジス夕になければなら ないということである。これらの半導体材料には、柔 軟かつ透明なポリマー基板を使用できるだけの低温 で処理できるという大きな長所がある。

しかし実際には、ディスプレイ中のトランジスタは、 好きなだけ大きくできるわけではない。画素中でトラ ンジスタが占める空間が広くなるほど、光を発するた めに使える空間が狭くなるからである。ディスプレイ 開発の重要な目標は、開口率（画素中で光を発する ために使用できる領域全体の割合）を大きくすること にある。アモルファスシリコン、または有機トランジス タで画素の大きさが 300 ～ $500 \mu \mathrm{m}$ であれば、40 〜 50\%の開口率が可能である ${ }^{3-5}$ 。

最初に大量生産されたアクティブマトリックス式 OLED ディスプレイ ${ }^{6}$ では、開口率を高めるために、 多結晶シリコンを原料とするトランジスタが用いられて いる。アモルファスシリコンまたは有機半導体と比べ ると、この半導体の電荷担体の移動度ははるかに大 きいため、トランジスタを細くして、開口率を大きくす ることができる。しかし、多結晶シリコントランジスタ は、より高い処理温度を必要とするため、ポリマー基 板と一緒に多結晶シリコンを用いることはむずかしい。

そこで半導体ナノワイヤーの出番となる。半導体ナ ノワイヤーは単結晶からできているため、電荷担体 の移動度は大きい。Ju らの報告 ${ }^{2}$ によると、彼らが 酸化インジウム $\left(\mathrm{In}_{2} \mathrm{O}_{3}\right)$ を使って作製したナノワイ ヤーでの值は $250 \mathrm{~cm}^{2} \mathrm{~V}^{-1} \mathrm{~S}^{-1}$ であったという。こう 
して、少数のナノワイヤーをうまく整列させたものは、 多結晶シリコントランジスタと同じ駆動電流を出力で きることになる。

$\mathrm{Ju}$ らは、パルスレーザーアブレーションによってナ ノワイヤーを作製した（図 1)。これは、レーザーを 使ってバルクの固体標的から材料を蒸発させたもの を、懸濁液中からディスプレイ基板上へと移す方法 である。ナノワイヤーがディスプレイ基板上に載つた ら、標準的なフォトリソグラフィー技術により、これ をトランジスタと画素回路につなぐ。余分なナノワイ ヤーは、超音波を使ってバス中で振り落とす。

ソース接点 (トランジスタの中を流れる電流の入口) とドレイン接点（同じく出口）、および、その電流の大 きさを制御するゲート電極に光学的に透明な導体を 用いることにより、透明ディスプレイに使えるトランジ ス夕が得られた。これは、車のフロントガラスなどに 使えるはずである。ゲート電極は、絶縁層によってナ ノワイヤーから分離しなければならない。そのために 著者らは、きわめて少ない欠陥と大きな電気容量をも つ、非常に薄い分子誘電体を使用した（図 la)。電 気容量が大きいということは、ナノワイヤー中に十分 な数の電荷担体を誘導するために必要とされるゲート 電圧が比較的小さく（約 4 ボルト）、ディスプレイの 電力消費を最小限に抑えられることを意味している。

ナノワイヤーをディスプレイ上で作らずに、あらかじ め作っておいたナノワイヤーを基板に移すという方法 をとることにより、半導体を作製するためのサーマル バジェットは、トランジスタを作製するためのサーマル バジェットから切り離される。ゆえに、十分な電荷担 体移動度をもつナノワイヤーを作製するためには高工 ネルギーまたは高温が必要であるが、ディスプレイは 低温のポリマー基板上で作製することができるのであ る。著者らのトランジス夕製作過程での最高温度は約 $100{ }^{\circ} \mathrm{C}$ あ゙り、これはフォトリソグラフィーのための温 度であった。一方、高移動度の多結晶シリコン薄膜 を用いるトランジスタは、約 $500^{\circ} \mathrm{C}$ での炉アニールか、 時間のかかるレーザー結晶化を必要とする。Ju ら ${ }^{2}$ はさらに、ナノワイヤーと室温で作製できる有機ゲート 誘電体との相性が非常によいことも示している。これ に対して、アモルファスおよび多結晶シリコンは、通常、 約 $200^{\circ} \mathrm{C}$ で堆積させる無機誘電体を必要とする。

画素の大きさが $54 \mu \mathrm{m} \times 176 \mu \mathrm{m}$ と比較的小さ い上に、特別なナノワイヤー配置方法がなく、トラン ジス夕領域の小さな部分しか電子輸送に利用できな いことを考えると、著者らが報告するディスプレイの 46\%という開口率は、かなりの值である（図 $1 \mathrm{~b}$ )。
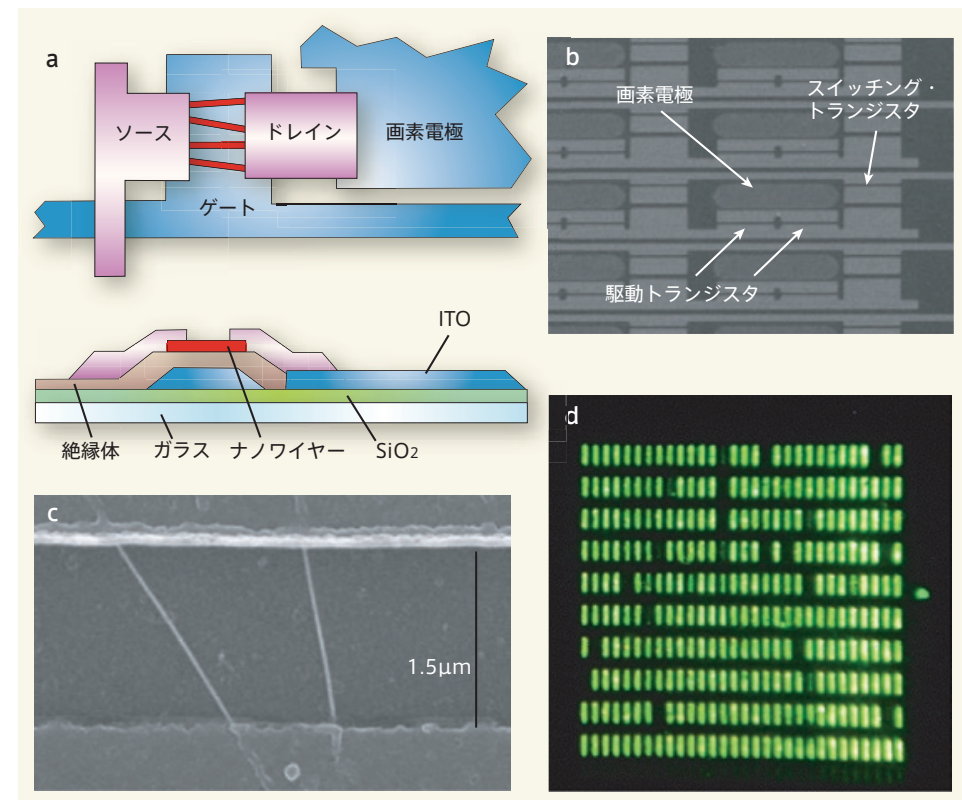

d

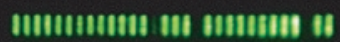

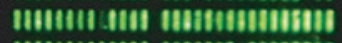

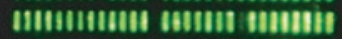
IIIIII IIIIIII! I IIIIIII

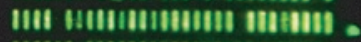

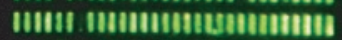

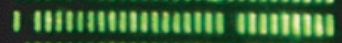

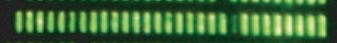

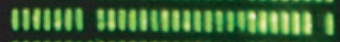

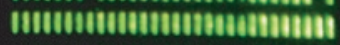

図 1 小型で、柔軟で、透明なディスプレイをめざして。a、このほどJuらが開 発したアクティブマトリックス式有機発光ダイオード (OLED) ディスプレイ用ト ランジスタ素子 ${ }^{2}$ の中核部分では、トランジスタのソースとドレインの間を酸化 インジウム製のナノワイヤーがつないでいる。トランジスタは酸化インジウムス ズ (ITO) という透明な導体でできている。ナノワイヤーとトランジスタのゲート 電極は薄い分子絶緑体によって分離されているため、トランジスタは小さい電圧 で制御することができる。b、ガラス基板上に二酸化ケイ素 $\left(\mathrm{SiO}_{2}\right)$ 層が載って いる構造は、ディスプレイの OLED から失われる領域を最小限に抑えることが できる。 $54 \mu \mathrm{m} \times 176 \mu \mathrm{m}$ の画素のいくつかを上から見たこの画像では、丸み を帯びた菱形が、利用可能な領域の約 46\%（ディスプレイの開口率）を占める OLED 電極である。c、素子の内部にあるナノワイヤー (斜線) の走査型電子顕 微鏡画像。d、トランジスタ動作電圧が $3 V 、 O L E D$ 駆動電圧が 5 Vで動作して いる $2 \mathrm{~mm} \times 2 \mathrm{~mm}$ ディスプレイ (図は参考文献 2 より引用)。

現段階では、このディスプレイはフルカラーではなく モノクロである。また、その応答は、ビデオレートの マトリックス・アドレッシングではなく、静的な画素 演算である。それでも、ナノワイヤートランジス夕を 使ったアクティブマトリックス式 OLED ディスプレイ の実証には大きな意義がある。我々に足りないのは、 効率のよいナノワイヤー配置方法（そしておそらく OLED の効率と寿命のもう少しの改善）だけである。 これさえ手に入れば、高品質の柔軟なディスプレイ が現実のものとなるかもしれないのだ。

Hagen Klauk、マックス・プランク固体研究所 (独)

1. Rustagi, S. C. et al. IEEE Electr.Device Lett.28, 1021-1024 (2007)

2. Ju, S. et al. Nano Lett. advance online publication doi:10.1021/nl072538+ (2008).

3. Long, K. et al. IEEE Trans.Electr.Devices 53, 1789-1796 (2006)

4. Kumar, A., Nathan, A. \& Jabbour, G. E. IEEE Trans. Electr.Devices $\mathbf{5 2}$ 2386-2394 (2005).

5. Zhou, L. et al. Appl. Phys. Lett.88, 083502 (2006).

6. www.sony.jp/products/Consumer/oel 